\title{
ANALISIS FAKTOR-FAKTOR YANG MEMPENGARUHI DIVIDEND PAYOUT RATIO PADA PERUSAHAAN MANUFAKTUR YANG TERDAFTAR DI BEI TAHUN 2008-2010
}

\author{
GUNAWAN ${ }^{5}$ \\ DINA FEBRIANA \\ (STIE INDONESIA BANKINGSCHOOL)
}

\begin{abstract}
This research was written in order to find out the relation between cash ratio, debt to equity ratio, firm size and growth to dividend payout ratio of the manufactur industry. The samples consisted of 20 manufactur companies from 2008 through 2010 and still listed on IDX.

Research sample using purposive sampling of companies for period ended 2008 - 2010 analyzed by using the two tail linear regression methodology. The analysis technique used here is multiple regression with the least square difference and hypothesis test using $t$-statistic to examine partial regression coefficient and F-statistic to examine the mean of mutual effect with level of significance $5 \%$.

The result showed that the factors that affect significantly to the dividend payout ratio were debt to equity ratio and growth.. The other factors such as cash ratio and firm size had no significant relations. But the other result of this research showed that cash ratio, debt to equity ratio, firm size and growth were simultaneously had significant affect to dividend payout ratio.
\end{abstract}

\section{Keywords : Cash Ratio, Debt to Equity Ratio, Firm Size, Growth and Dividend Payout} Ratio

\section{PENDAHULUAN}

Dalam menetapkan kebijakan dividen, seorang manager keuangan menganalisis sampai seberapa jauh pembelanjaan dari dalam perusahaan sendiri yang akan dilakukan oleh perusahaan dapat dipertanggungjawabkan. Hal ini mengingat bahwa hasil operasi yang ditanamkan kembali dalam perusahaan sesungguhnya adalah dana pemilik perusahaan yang tidak dibagikan sebagai dividen.

Berdasarkan Bursa Efek Jakarta (Indonesian Capital Market Directory, 1999-2003), pada periode tahun 1999-2003 hanya sedikit perusahaan manufaktur yang membagikan deviden secara stabil selama lima tahun berturut-turut. Dari total 154 perusahaan hanya 17 perusahaan yang mampu memberikan deviden selama 5 tahun berturut-turut. Sedangkan pada periode 20082010 hanya 20 perusahaan manufaktur yang membagikan dividennya selama tiga tahun berturut-turut dari total 131 perusahaan yang terdaftar di Bursa Efek Indonesia (Indonesian Capital Market Directory 2010). Disamping itu,besaran deviden payout yang dibagikan juga relatif fluktuatif, dimana hal ini sangat menarik mengingat tujuan utama perusahaan adalah untuk kesejahteraan bagi para pemilik dan pemegang sahamnya. 
Penelitian terhadap faktor-faktor yang mempengaruhi kebijakan pembagian dividen payout ratio sudah banyak yang dilakukan. Namun, masing-masing terdapat perbedaan dari hasil penemuannya. Variabel cash ratio dinyatakan berpengaruh positif signifikan terhadap DPR pada penelitian Risaptoko (2007), namun berbeda dengan hasil penelitian Winatha (2001) dimana cash ratio tidak memiliki pengaruh terhadap DPR. Variabel debt to equity ratio dinyatakan berpengaruh negatif signifikan terhadap DPR pada penelitian Dyah (2010) namun kontradiktif dengan hasil penelitian Rini (2007) dimana debt to equity ratio berpengaruh negatif tidak signifikan. Variabel size dinyatakan berpengaruh positif signifikan pada penelitian terhadap DPR oleh Fira (2009) namun kontradiktif dengan hasil penelitian Hatta (2002) dimana variabel size berpengaruh positif tidak signifikan. Variabel growth penelitian Saxena (1999) dan Fira (2009) dinyatakan berpengaruh negatif signifikan terhadap DPR sedangkan hasil penelitian Amalia (2008), variabel growth tidak berpengaruh terhadap DPR.

Dengan melihat adanya relative sedikitnya perusahaan manufaktur yang membagi dividen secara berturut-turut, dan adanya inkonsistensi hasil penelitian-penelitian terdahulu, maka perlu diteliti lebih lanjut faktor-faktor yang mempengaruhi kebijakan dividen payout ratio dengan membatasi penelitian menggunakan variabel cash ratio, debt to equity ratio, firm size, dan growth terhadap perusahaan manufaktur yang terdaftar di Bursa Efek Indonesia periode 2008-2010. Selanjutnya penelitian diberi judul Analisis Faktor-faktor yang Mempengaruhi Kebijakan Dividend Payout Ratio dengan menggunakan variabel cash ratio, debt to equity ratio, firm size dan growth terhadap perusahaan manufaktur yang terdaftar di Bursa Efek Indonesia periode 2008-2010.

\subsection{Perumusan Masalah}

1. Apakah cash ratio memiliki pengaruh terhadap dividend payout ratio pada perusahaan manufaktur yang terdaftar di Bursa Efek Indonesia periode 2008-2010?

2. Apakah debt to equity ratio memiliki pengaruh terhadap dividend payout ratio pada perusahaan manufaktur yang terdaftar di Bursa Efek Indonesia periode 2008-2010?

3. Apakah firm size memiliki pengaruh terhadap dividend payout ratio pada perusahaan manufaktur yang terdaftar di Bursa Efek Indonesia periode 2008-2010?

4. Apakah growth memiliki pengaruh terhadap dividend payout ratio pada perusahaan manufaktur yang terdaftar di Bursa Efek Indonesia periode 2008-2010?

5. Apakah cash ratio, debt to equity ratio, firm size dan growth memiliki pengaruh secara simultan terhadap dividend payout ratio pada perusahaan manufaktur yang terdaftar di Bursa Efek Indonesia periode 2008-2010?

\subsection{Pembatasan Masalah}

1. Variabel yang diteliti hanya empat variabel, antara lain : cash ratio, debt to equity, firm size, growth dan dividend payout ratio.

2. Perusahaan yang diteliti hanya perusahaan manufaktur yang terdaftar di Bursa Efek Indonesia.

3. Periode yang digunakan yaitu tahun 2008-2010. 


\section{TINJAUAN PUSTAKA DAN PENGEMBANGAN HIPOTESIS}

\subsection{Pengertian dan Teori Kebijakan Dividen}

Menurut Ross et al (2008), Ross menyatakan bahwa dividen adalah suatu bentuk pembayaran yang dilakukan oleh perusahaan kepada para pemiliknya, baik dalam bentuk kas maupun saham. Dividen dikatakan juga sebagai "komponen pendapatan" dari return investasi pada saham.

Beberapa teori yang berkaitan dengan kebijakan dividen:

\section{Bird in the hand theory}

Sementara itu, menurut Gordon dan Litner (Brigham dan Houston 2004) tingkat keuntungan yang disyaratkan akan naik apabila pembagian dividen dikurangi, karena investor lebih yakin terhadap penerimaan dividen daripada kenaikan nilai modal (capital gain) yang akan dihasilkan dari laba yang ditahan. Modigliani dan Miller (1961) berpendapat dan telah dibuktikan secara matematis bahwa investor merasa sama saja apakah menerima dividen saat ini atau menerima capital gain di masa yang akan datang. Dengan kata lain, tingkat keuntungan yang disyaratkan tidak dipengaruhi oleh dividen payout ratio. Pendapat Modigliani dan Miller (1961) oleh Gordon dan Litner (Brigham dan Houston 2004) diberi nama bird in the hand fallacy. Gordon dan Litner (Saxena 1999) beranggapan investor memandang bahwa satu burung di tangan lebih berharga daripada seribu burung di udara. Sementara Modigliani dan Miller berpendapat bahwa tidak semua investor berkepentingan untuk menginvestasikan kembali dividen mereka di perusahaan yang sama dengan memiliki risiko yang sama. Oleh sebab itu, tingkat risiko pendapatan mereka di masa yang akan datang bukannya ditentukan oleh dividen payout ratio tetapi ditentukan oleh tingkat risiko investasi baru.

\section{Tax preference theory}

Menurut Litzenberger dan Ramaswamy dalam Brigham (1996), jika capital gain dikenakan pajak dengan tarif lebih rendah daripada pajak atas dividen, maka saham yang memiliki pertumbuhan tinggi menjadi lebih menarik. Tetapi sebaliknya jika capital gain dikenai pajak yang sama dengan pendapatan atas dividen, maka keuntungan capital gain menjadi berkurang. Namun demikian pajak atas dividen karena pajak atas capital gain baru dibayar setelah saham dijual, sementara pajak atas dividen harus dibayar setiap tahun setelah pembayaran dividen. Selain itu periode investasi juga mempengaruhi pendapatan investor. Jika investor hanya membeli saham untuk jangka waktu satu tahun, maka tidak ada bedanya antara pajak atas capital gain dan pajak atas dividen. Jadi investor akan meminta tingkat keuntungan setelah pajak yang lebih tinggi terhadap saham yang memiliki dividen yield yang tinggi daripada saham dengan dividen yield yang rendah. Oleh karena itu, teori ini menyarankan bahwa perusahaan sebaiknya menentukan dividen payout ratio yang rendah atau bahkan tidak membagikan dividen.

\section{Information Content of Dividend}

Beberapa studi empiris memperlihatkan bahwa harga saham di pasar berubah sesuai dengan perubahan pengumuman dividen. Artinya pengumuman jumlah dividen yang akan dibagi kepada para pemegang saham akan menggambarkan suatu informasi mengenai prospek 
perusahaan tersebut. Berubahnya harga saham sesuai dengan perubahan pengumuman besarnya dividen karena adanya informasi yang terkandung dalam dividen (the information content of dividend), mengingat besarnya current dividend merupakan ukuran harapan pendapatan perusahaan masa mendatang yang disampaikan kepada investor melalui perubahan dividen (Jensen, 1992). Hal ini dapat dimengerti bahwa sepertinya mustahil suatu perusahaan mengumumkan untuk menikkan dividen apabila prospek pada waktu yang akan dating.

\section{Cilentele Effect}

Menurut Bringham dan Houston (2004) clientele effect adalah kecenderungan sebuah perusahaan untuk menarik sekumpulan investor yang menyukai kebijakan dividennya. Pendapat ini didukung oleh Ross, Westerfeld, dan Jordan (2008) yang menyatakan clientele effect adalah suatu fakta yang dapat diobservasi bahwa saham menarik kelompok tertentu berdasarkan pendapatan dividend an efek pajak. Argumen mengenai clientele effect menyatakan bahwa kelompok investor yang berbeda menginginkan tingkat dividen yang berbeda. Ketika perusahaan memilih kebijakan dividen tertentu, satu-satunya akibat dari kebijakan ini adalah untuk menarik kelompok investor tertentu dan apabila perusahaan mengubah kebijakan dividennya maka hal ini dilakukan untuk menarik kelompok investor yang berbeda.

\subsubsection{Faktor-faktor yang Mempengaruhi Kebijakan Dividen}

Menurut Brigham dan Gapenski (1997) penentuan kebijakan dividen dipengaruhi oleh beberapa faktor sebagai berikut:

1. Bond Indentures

Merupakan kontrak pinjaman yang membatasi jumlah pembayaran dividen. Kontrak pinjaman ini sering kali menetapkan tidak adanya dividen yang dibayarkan kecuali current ratio, times earned ratio, dan rasio keamanan lainnya lebih baik dari nilai minimum yang ditetapkan.

2. Preferred Stock Restriction

Pembayaran dividen untuk saham biasa tidak dilakukan jika dividen saham preferen belum dibayar.

3. Impairment of Capital Rules

Mengenai peraturan laba bersih yang menyatakan bahwa dividen dapat dibayar dari laba saat ini atau laba tahun lalu. Adanya larangan pengurangan modal untuk membayar dividen, hal ini dimaksudkan untuk melindungi pemberi kredit. Peraturan kepailitan yang menyatakan jika perusahaan membayar dividen pada kondisi pailit artinya dana tersebut berasal dari pemberi kredit bukan dari laba bersih perusahaan.

4. A vailability of Cash

Merupakan dividen tunai yang hanya dapat dibayar dengan uang kas. Kekurangan uang kas di bank akan membatasi pembayran dividen walaupun dana pinjaman yang tidak digunakan dapat digunakan untuk menutupi kekurangannya.

5. Penalty Tax on Improperly Accumulated Earnings 
Peraturan ini dibuat untuk mencegah individu yang menggunakan perusahaan untuk menghindari pajak perorangan. Ada denda yang berat bagi perusahaan bila hal itu benar dapat dibuktikan kejadiannya.

6. Control

Jika manajemen bermaksud untuk menjaga kontrol perusahaan, mereka enggan untuk menjual saham baru. Agar hal itu tidak terjadi maka perusahaan harus menahan lebih banyak labanya.

7. Signaling Theory

Manajer dapat menggunakan dividen untuk menunjukkan kondisi perusahaan. Jumlah dividen yang besar menunjukkan bahwa kondisi perusahaan baik, begitu juga sebaliknya. Dividen dalam jumlah kecil menunjukkan kondisi perusahaan yang kurang baik.

\subsubsection{Dividend Payout Ratio}

Dividend Payout Ratio adalah perbandingan anatara dividend per share dengan earning per share (Ang, 1997). DPR merupakan presentase dari pendapatan yang akan dibayarkan kepada para pemegang saham sebagai cash dividend (Riyanto, 2001).

Rasio pembayaran dividen (dividend payout ratio) menentukan jumlah laba yang dibagi dalam bentuk dividen kas dan laba yang ditahan sebagai sumber pendanaan. Rasio ini menunjukkan persentase laba perusahaan yang dibayarkan kepada pemegang saham yang berupa dividen kas. Apabila laba perusahaan yang ditahan untuk keperluan operasional perusahaan dalam jumlah besar, berarti laba yang akan dibayarkan sebagai dividen menjadi lebih kecil. Sebaliknya jika perusahaan lebih memilih untuk membagikan laba sebagai dividen, maka hal tersebut akan mengurangi porsi laba ditahan dan mengurangi sumber pendanaan intern. Namun, dengan lebih memilih membagikan laba sebagai dividen tentu saja akan meningkatkan kesejahteraan para pemegang saham, sehingga para pemegang saham akan terus menanamkan sahamnya untuk perusahaan tersebut.

\section{Faktor-faktor yang Berpengaruh terhadap Dividend Payout Ratio}

\section{Cash Ratio}

Cash ratio merupakan salah satu ukuran dari rasio likuiditas (liquidity ratio) yang merupakan kemampuan perusahaan memenuhi kewajiban jangka pendeknya (current liability) melalui sejumlah kas (dan setara kas, seperti giro atau simpanan lain di bank yang dapat ditarik setiap saat) yang dimiliki perusahaan. Semakin tinggi cash ratio menunjukkan kemampuan kas perusahaan untuk memenuhi (membayar) kewajiban jangka pendeknya (Brigham, 2004). Dengan semakin meningkatnya cash ratio juga dapat meningkatkan keyakinan para investor untuk membayar dividen yang diharapkan oleh investor.

\section{Debt to Equity Ratio}

Rasio hutang perusahaan berupa Debt Equity Ratio (DER) mencerminkan kemampuan perusahaan dalam memenuhi seluruh kewajibannya yang ditunjukkan oleh beberapa bagian modal sendiri yang digunakan untuk membayar hutang. Semakin besar rasio ini, menunjukkan 
semakin besar kewajibannya dan begitu juga sebaliknya. Peningkatan hutang ini akan mempengaruhi tingkat pendapatan bersih yang tersedia bagi pemegang saham, artinya tingginya kewajiban perusahaan akan semakin menurunkan kemampuan perusahaan dalam membayar dividen. Rozeff (1982) menunjukkan bahwa perusahaan dengan tingkat solvabilitas permodalan yang tinggi cenderung memiliki rasio pembayaran rendah untuk mengurangi biaya yang berkaitan dengan transaksi pembiayaan eksternal. Selain itu, ada beberapa perjanjian hutang yang membatasi pembayaran dividen.

\section{Firm Size}

Perusahaan besar dengan akses pasar yang lebih baik seharusnya membayar dividen yang tinggi kepada pemegang sahamnya, sehingga antara ukuran perusahaan dan pembayaran dividen memiliki hubungan yang positif (Farinha, 2002).

Suatu perusahaan besar yang sudah mapan akan memiliki akses yang mudah menuju pasar modal, sementara perusahaan yang baru dan yang masih kecil akan mengalami banyak kesulitan untuk memilki akses ke pasar modal. Karena kemudahan akses ke pasar modal cukup berarti untuk fleksibilitas dan kemampuannya untuk memperoleh dana yang lebih besar, sehingga perusahaan mampu memiliki rasio pembayaran dividen yang lebih tinggi daripada perusahaan kecil (Chang dan Rhee, 1990).

\section{Growth}

Semakin tinggi tingkat pertumbuhan perusahaan, akan semakin besar tingkat kebutuhan dana untuk membiayai ekspansi. Semakin besar kebutuhan dana di masa yang akan datang, akan semakin memungkinkan perusahaan menahan keuntungan dan tidak membayarkannya sebagai dividen. Oleh karenanya, potensi pertumbuhan perusahaan menjadi faktor penting yang menentukan kebijakan dividen (Chang dan Reee, 1990). Pertumbuhan perusahaan menggambarkan tolak ukur keberhasilan perusahaan. Keberhasilan tersebut juga menjadi tolak ukur investasi untuk pertumbuhan pada masa yang akan datang (Yuningsih, 2002).

\subsection{Rerangka Penelitian}

Berdasarkan pada kajian teori dan hasil penelitian terdahulu mengenai hubungan antara cash ratio, debt to equity ratio, firm size, growth dan dividend payout ratio, maka permasalahan dalam penelitian ini dapat digambarkan dengan kerangka pemikiran sebagai berikut : 


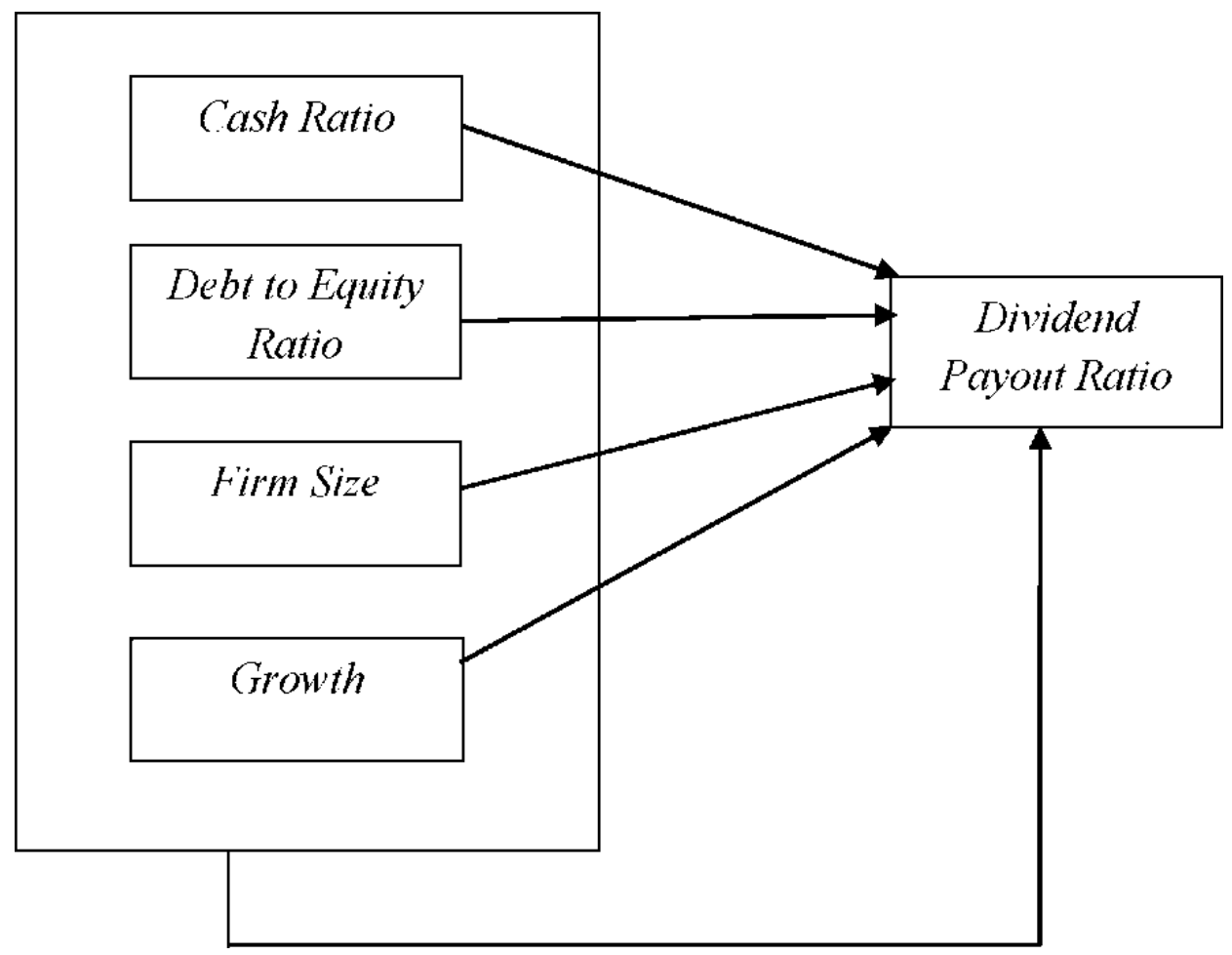

\subsection{Hipotesa}

Ha1 : Cash Ratio berpengaruh terhadap dividend payout ratio perusahaan manufaktur yang terdaftar di Bursa Efek Indonesia periode 2008-2010.

Ha2 : Debt to equity ratio berpengaruh terhadap dividend payout ratio perusahaan manufaktur yang terdaftar di Bursa Efek Indonesia periode 2008-2010.

Ha3 : Firm size berpengaruh terhadap dividend payout ratio perusahaan manufaktur yang terdaftar di Bursa Efek Indonesia periode 2008-2010.

Ha4 : Growth berpengaruh terhadap dividend payout ratio perusahaan manufaktur yang terdaftar di Bursa Efek Indonesia periode 2008-2010.

Ha5 : Cash ratio, debt to equity ratio, firm size dan growth berpengaruh secara simultan terhadap dividend payout ratio perusahaan manufaktur yang terdaftar di Bursa Efek Indonesia periode 2008-2010.

\section{METODOLOGI PENELITIAN}

\subsection{Objek Penelitian}

Objek pada penelitian ini adalah perusahaan manufaktur yang terdaftar pada Bursa Efek Indonesia periode tahun 2008 - 2010..

\subsection{Populasi dan Teknik Pengambilan Sampel}

Berdasarkan data yang diperoleh dari Indonesian Capital Market Directory (ICMD) 2010 bahwa jumlah perusahaan bank umum yang terdaftar pada Bursa Efek Indonesia adalah 131 perusahaan manufaktur. Teknik pemilihan sampel menggunakan metode purposive sampling . 
Dari 131 perusahaan tersebut terdapat 111 perusahaan yang tidak memiliki data-data terkait dengan penelitian selama periode penelitian, sehingga jumlah perusahaan manufaktur yang dapat memenuhi kriteria adalah 20 perusahaan

\subsection{Teknik Pengumpulan Data}

Teknik pengumpulan data untuk keperluan penelitian ini dilakukan dengan dokumentasi. Dokumentasi yang dilakukan adalah dengan mengumpulkan semua data sekunder yang dipublikasikan oleh Jakarta Stock Exchange (JSX) Monthly Statistic, Indonesian Capital Market Directory tentang perusahaan yang terdaftar di Bursa Efek Indonesia periode 2008-2010.

\subsection{Metode Analisis Data}

\subsubsection{Varibel Penelitian dan Pengukuran Variabel}

Dalam penelitian ini variabel diklasifikasikan menjadi dua kelompok variable yaitu variable independen dan variabel dependen. Variabel independen adalah cash ratio (X1), debt to equity ratio (X2), firm size (X3) dan growth (X4) sedangkan variabel dependen adalah dividend payout ratio $(\mathrm{Y})$.

\section{Variabel Dependen (Y)}

Dividend Payout Ratio (DPR) merupakan indikasi atas prosentase jumlah penghasilan yang diperoleh dan kemudian didistribusikan kepada pemilik atau pemegang saham dalam bentuk kas (Gitman, 2003). Dividend Payout Ratio ini ditentukan perusahaan untuk membayar dividen kepada para pemegang saham setiap tahun, penentuan DPR berdasarkan besar kecilnya laba setelah pajak.

$$
D P R(Y)=\frac{D P S}{E P S}
$$

Dimana:

DPR (Y) : Rasio pembayaran dividen

DPS : Dividen per lembar saham

EPS : Laba per lembar saham

\section{Variabel Independen (X)}

\section{Cash Ratio (CR)}

Cash ratio merupakan salah satu ukuran dari rasio likuiditas (liquidity ratio) yang merupakan kemampuan perusahaan memenuhi kewajiban jangka pendeknya (current liability) melalui sejumlah kas (dan setara kas, seperti giro atau simpanan lain di bank yang dapat ditarik setiap saat) yang dimiliki perusahaan. Variabel ini diberi simbol X1.

(Kas + setara kas) /Hutangjangkapendek 


\section{Debt to Equity Ratio (DER)}

Menurut Riyanto (2001), salah satu rasio yang termasuk dalam rasio solvabilitas atau leverage adalah Debt to Equity Ratio(DER). Rasio ini digunakan untuk mengetahui berapa bagian dari setiap modal sendiri yang dijadikan jaminan untuk leseluruhan hutang perusahaan atau untuk menilai banyaknya hutang yang digunakan oleh perusahaan. Semakin kecil rasio ini semakin baik. Untuk keamanan pihak luar rasio terbaik jika jumlah modal lebih besar dibandingkan dengan jumlah hutang atau minimal sama. Jika dihubungkan dengan pembayaran dividen maka akan berlaku hubungan yang berlawanan (negatif), artinya semakin besar rasio ini maka akan semakin kecil pembayaran dividend dan sebaliknya. Variabel ini diberi simbol X2.

\section{Total hutanq}

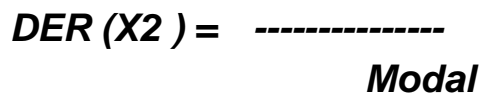

\section{Firm Size (FirmSize)}

Ukuran perusahaan adalah skala besar kecilnya perusahaan yang ditentukan oleh beberapa hal antara lain total penjualan, total aktiva, dan rata-rata tingkat penjualan perusahaan.Variabel ini diberi simbol X3 dan diukur dengan menggunakan natural logaritma dari net sales (Moh'd Perry dan Rimbey,1995 dalam Yuniningsih, 2002).

Firm Size $(X 3)=L$ of ne $t$ sales

\section{Growth}

Pertumbuhan perusahaan adalah gambaran tolak ukur keberhasilan perusahaan. Aset adalah aktiva yang digunakan untuk aktivitas operasional perusahaan. Semakin besar aset maka diharapkan semakin besar pula hasil operasional yang dihasilkan oleh suatu perusahaan. (Ang, 1997). Variabel ini diberi simbol X2 Sumber data dari variabel ini diperoleh dari Indonesian Capital Market Directory. Pertumbuhan perusahaan dapat diukur dengan menggunakan rumus sebagai berikut (Yuniningsih,2002):

$$
\operatorname{Growth}(X)=\frac{(S t-S t-1)}{S t-1}
$$

dimana:

X4= pertumbuhan perusahaan

St $=$ total aset tahun berjalan

St-1=total aset tahun sebelumnya 


\subsubsection{Teknik Pengujian Hipotesis}

Rancangan penelitian yang digunakan dalam penelitian ini adalah metode Multiple Regression Linear Analysis. Penelitian ini merupakan pengujian hipotesis karena peneliti ingin mengetahui dan manganalisa bagaimana pengaruh yang signifikan antara cash ratio, debt equity ratio, firm size dan, growth rate terhadap dividend pay out ratio.

Uji t untuk menganalisa pengaruh secara parsial dan uji $\mathrm{F}$ untuk menguji pengaruh secara simultan, keduanya menggunakan $\alpha=5 \%$.

Perkiraan persamaan regresi yang digunakan adalah sebagai berikut:

$$
D P R=b 0+b 1(C R)+b 2(D E R)+b 3(F I R M ~ S I Z E)+b 4(G R O W T H)+e
$$

Keterangan:

$$
\begin{aligned}
& e=\text { error term, } \\
& \text { b0 }=\text { konstanta }
\end{aligned}
$$

b1,b2,b3,b4 = koefisien regresi

\section{ANALISIS DAN PEMBAHASAN}

\subsection{Analisis Deskriptif}

Pada bagian ini akan disajikan statistika deskripsi dari variabel independen maupun variabel dependen. Variabel yang digunakan dalam penelitian ini adalah DPR, Cash Ratio, DER dan Firm Size. Aanlisis ini dimaksudkan untuk menjelaskan karakteristik sampel terutama mencakup nilai rata-rata, nilai ekstrim yaitu nilai minimum dan nilai maksimum, serta standar deviasi. Data yang digunakan dalam penelitian ini untuk masing-masing variabel berjumlah 60 yang diperoleh dari 20 perusahaan dikalikan periode tahun pengamatan (3 tahun). Berikut ini adalah hasil statistik deskriptif dari data yang digunakan dalam penelitian ini:

\section{Tabel 4.1}

Hasil Statistik Deskriptif

\begin{tabular}{|l|c|c|c|c|c|}
\hline & DPR & CR & DER & G & FS \\
\hline Mean & 48.69783 & 1.082924 & 0.910000 & 0.131452 & 15.06237 \\
\hline Median & 40.02500 & 0.552789 & 0.465000 & 0.113550 & 14.70688 \\
\hline Maximum & 107.3900 & 5.184492 & 8.440000 & 0.763700 & 18.68298 \\
\hline Minimum & 18.56000 & 0.023961 & 0.140000 & 0.006000 & 12.19353 \\
\cline { 3 - 6 }
\end{tabular}

Sumber: Data sekunder yang diolah

\subsection{Analisis Hasil Regresi}

Berdasarkan hasil pengujian dengan metode regresi linier berganda dapat disusun sebuah persamaan sebagai berikut :

DPR $=21.656+0.543$ Cash ratio -0.904 DER -0.965 FirmSize -0.827 Growth 


\subsubsection{Hasil Uji t}

Berdasarkan uji t diperoleh hasil

\section{Cash Ratio}

Variabel cash ratio memiliki nilai probability sebesar 0.7005 . Nilai probability dari variabel cash ratio lebih besar dari 0.05 , Dengan demikian secara parsial Ho diterima hal ini berarti variabel cash ratio tidak berpengaruh terhadap dividend payout ratio pada perusahaan manufaktur yang terdaftar di Bursa Efek Indonesia periode 2008-2010.

Penelitian ini didukung oleh hasil penelitian Rini (2007) yang menunjukkan bahwa Cash Ratio tidak terbukti berpengaruh terhadap DPR. Hal ini mungkin dikarenakan likuiditas bukan digunakan membayar dividen tetapi untuk melunasi hutang lancarnya agar tepat waktu atau dialokasikan pada pembelian aktiva tetap atau aktiva lancar yang permanen, guna memanfaatkan kesempatan investasi yang ada serta untuk biaya operasional.

\section{Debt to Equity Ratio}

Variabel debt to equity ratio memiliki nilai probability sebesar 0.0015 . Nilai probability dari variabel debt to equity ratio lebih kecil dari 0.05 , Dengan demikian secara parsial hipotesis Ho ditolak, hal ini berarti bahwa variabel debt to equity ratio berpengaruh terhadap dividend payout ratio pada perusahaan manufaktur yang terdaftar di Bursa Efek Indonesia periode 2008-2010.

Pengujian terhadap variabel DER menunjukkan bahwa variabel DER berpengaruh negatif terhadap DPR. Penelitian ini didukung oleh hasil penelitian Sutrisno (2001) dimana DER mencerminkan kemampuan perusahaan dalam memenuhi seluruh kewajibannya. Hal ini menunjukkan bahwa semakin tinggi tingkat DER, berarti komposisi hutang juga semakin tinggi, sehingga akan berakibat pada semakin rendahnya kemampuan untuk membayar dividen. Setiap kenaikan DER akan menurunkan kemampuan perusahaan untuk membayar dividen kepada para pemegang saham.

\section{Firm Size}

.Nilai probability dari variabel firm size lebih besar dari 0.05 . Dengan demikian secara parsial hipotesis Ho diterima, hal ini berarti bahwa variabel firm size tidak berpengaruh terhadap dividend payout ratio pada perusahaan manufaktur yang terdaftar di Bursa Efek Indonesia periode 2008-2010..

Pengujian terhadap variabel Firm Size menunjukkan bahwa variabel Firm Size tidak berpengaruh terhadap Dividend Payout Ratio, artinya tidak ada pengaruh antara perusahaan besar maupun perusahaan kecil dalam melakukan kebijakan dividen, hal ini mungkin dikarenakan dalam kondisi perekonomian yang kondusif, baik perusahaan kecil maupun besar akan lebih berorientasi pada pengembangan usaha (ekspansi) guna memperluas pasar. Hasil penelitian ini sesuai dengan penelitian yang dilakukan oleh Hatta (2002). 


\section{Growth}

Nilai probability dari variabel growth lebih kecil dari 0.05. Dengan demikian secara parsial Ho ditolak., hal ini berarti bahwa variabel growth berpengaruh terhadap dividend payout ratio pada perusahaan manufaktur yang terdaftar di Bursa Efek Indonesia periode 2008-2010. Pengujian terhadap variabel growth menunjukkan bahwa vatriabel growth berpengaruh negatif terhadap DPR. Hasil penelitian ini didukung dengan penelitian yang dilakukan oleh Saxena (1999). Dikatakan bahwa manajer perusahaan dengan memperhatikan pertumbuhan asset lebih menyukai untuk menginvestasikan laba setelah pajaknya yang tinggi, sehingga laba yang dibagi sebagai dividen rendah akibatnya DPR juga akan lebih rendah

\section{Tabel 4.2}

Hasil Regresi dan

\begin{tabular}{|l|c|c|l|}
\hline \multicolumn{1}{|c|}{ Varaibel } & Koefisien regresi & Signifikansi & \multicolumn{1}{c|}{ Kesimpulan } \\
\hline Constanta & 21.6557 & & \multicolumn{1}{|c|}{$\begin{array}{l}\text { Terima Ho, tidak } \\
\text { signifikan }\end{array}$} \\
\hline Cash Ratio & 0.54255 & 0.7005 & Tolak Ho, signifikan \\
\hline $\begin{array}{l}\text { Debt equity } \\
\text { ratio }\end{array}$ & -0.90427 & 0.0015 & Tolak Ho, signifikan \\
\hline Firm size & -0.82773 & 0.0247 & $\begin{array}{l}\text { Terima Ho, tidak } \\
\text { signifikan }\end{array}$ \\
\hline Growth & -0.96543 & 0.4954 & \multicolumn{2}{|c|}{} \\
\hline
\end{tabular}

\section{Sumber : Data sekunder diolah}

\subsubsection{Hasil Uji F}

Berdasarkan hasil uji statistik F, Nilai probability sebesar 0.000004 lebih kecil dibanding tingkat signifikansi $\mathrm{a}=0.05$ dan artinya Ha diterima atau Ho ditolak. Hal ini menandakan bahwa variabel-variabel independen (cash ratio, debt to equity ratio, firm size dan growth) berpengaruh secara simultan terhadap variabel dependen (dividend payout ratio).

Tabel 4.3

Effects Specification

Cross-section fixed (dummy variables)

\begin{tabular}{llll}
\hline R-squared & 0.776161 & Mean dependent var & 48. \\
& & & 69783 \\
Adjusted R-squared & 0.633153 & S.D. dependent var & 23.72002 \\
S.E. of regression & 14.36672 & Akaike info criterion & 8.456880 \\
Sum squared resid & 7430.492 & Schwarz criterion & 9.294618 \\
Log likelihood & -229.7064 & Hannan-Quinn criter. & 8.784565 \\
F-statistic & 5.427388 & Durbin-Watson stat & 2.631996 \\
Prob(F-statistic) & 0.000004 & &
\end{tabular}

Sumber: Data sekunder yang diolah 


\subsubsection{Koefisien Determinasi ( $R$ )}

Berdasarkan tabel 4.3 dapat dilihat hasil Adjusted $R$-squared sebesar 0.633153, hal ini menunjukkan bahwa $63.32 \%$ dari total variasi dependen dapat dijelaskan oleh model yang disajikan. Variabel cash ratio, DER, firm size dan growth hanya mampu menjelaskan variabel dependen dividend payout ratio sebesar $63.32 \%$ sedangkan $36.68 \%$ dijelaskan oleh faktor lain yang tidak masuk dalam model penelitian. Hal ini menunjukkan bahwa masih banyak faktor lain di luar faktor cash ratio, DER, firm size dan growth yang berpengaruh terhadap dividend payout ratio pada perusahaan industri manufaktur yang terdaftar di Bursa Efek Indonesia pada periode pengamatan 2008-2010.

\subsection{Implikasi Manajerial}

Hasil penelitian menunjukkan bahwa dari beberapa faktor fundamental perusahaan yang dapat mempengaruhi dividend payout ratio pada perusahaan manufaktur yang terdaftar pada Bursa Efek Indonesia adalah variabel debt to equity ratio dan growth. Variabel debt to equity ratio dan growth memiliki hubungan yang negatif signifikan terhadap dividend payout ratio, dimana semakin rendah nilai debt to equity ratio dan growth suatu perusahaan maka semakin tinggi nilai dividend payout ratio. Oleh karena itu, nilai debt to equity ratio dan growth yang baik untuk dijadikan tolak ukur return yang tinggi adalah nilai debt to equity ratio dan growth yang rendah.

\section{PENUTUP}

\subsection{Kesimpulan}

Berdasarkan hasil analisis yang dilakukan terdapat beberapa kesimpulan, antara lain:

1. Secara parsial variabel cash ratio tidak berpengaruh signifikan terhadap dividend payout ratio. Hal ini mungkin dikarenakan likuiditas bukan digunakan membayar dividen tetapi untuk melunasi hutang lancarnya agar tepat waktu atau dialokasikan pada pembelian aktiva tetap atau aktiva lancar yang permanen.

2. Secara parsial variabel debt to equity ratio berpengaruh signifikan terhadap dividend payout ratio. Hal ini mungkin dikarenakan perusahaan-perusahaan yang profitable memiliki lebih banyak earnings yang tersedia untuk investasi dan cenderung membangun equitas mereka relatif terhadap debt.

3. Secara parsial variabel firm size tidak berpengaruh signifikan terhadap dividend payout ratio. Hal ini mungkin dikarenakan dalam kondisi perekonomian yang kondusif, baik perusahaan kecil maupun besar akan lebih berorientasi pada pengembangan usaha (ekspansi) guna memperluas pasar.

4. Secara parsial variabel growth berpengaruh signifikan terhadap dividend payout ratio. Hal ini mungkin dikarenakan manajer perusahaan dengan memperhatikan pertumbuhan lebih menyukai untuk menginvestasikan laba setelah pajak dan mengharapkan kinerja yang lebih baik dalam asset growth secara keseluruhan.

5. Secara simultan variabel independen (cash ratio, debt to equity ratio, firm size dan growth) berpengaruh signifikan terhadap variabel dependen (dividend payout ratio) 


\subsection{Saran}

Berdasarkan hasil penelitian dan kesimpulan yang disajikan, terdapat berbagai saran bagi para pelaku pasar modal di masa yang akan datang..

1. Bagi investor, calon investor, atau pemegang saham

Faktor debt to equity ratio dan growth memiliki pengaruh signifikan terhadap dividend payout ratio perusahaan, oleh karena itu bagi para investor yang menyukai pengembalian investasi berupa dividen sebaiknya memilih perusahaan yang memiliki debt to equity ratio dan growth yang rendah sebelum melakukan investasi.

2. Bagi perusahaan

Manajer perusahaan perlu memperhatikan debt to equity ratio dan growth karena kedua faktor tersebut berpengaruh terhadap dividend payout ratio.

\section{DAFTAR PUSTAKA}

Amalia Chasanah. 2008. Analisis Faktor-faktor yang Mempengaruhi Dividend Payout Ratio pada Perusahaan yang Listed di BEl. Tesis. Universitas Diponegoro.

Ang, R (1997). "Buku Pintar Pasar Modal Indonesia (The Intelligent Guide to Indonesian Capital Market)". Media Soft Indonesia.

Brigham, Eugene F.,Gapenski, Louis C. 1996. Intermediate Financial Management. Sea Harbor Drive : The Dryden Press.

Brigham, Eugene, and Houston, J.F, 2004, Fundamentals of Financial Management (terjemahan), Salemba Empat, Jakarta

Chang, R.P, and Rhee, S.G. 1990. "Tax and Dividends: The Impact of Personal, Tax on Corporate Dividen Policy and Capital structure Decisions". Financial Manajemen/Summer.

Dyah Handayani. 2010. Analisis Faktor-faktor yang Mempengaruhi Dividend Payout Ratio pada Perusahaan Manufaktur di Bursa Efek Indonesia Periode 2005-2007. Skripsi. Universitas Diponegoro.

Fira Puspita. 2009. Analisis Faktor-faktor yang Mempengaruhi Dividend Payout Ratio pada Perusahaan yang Terdaftar di BEI Periode2005-2007. Tesis. Universitas Diponegoro

Hatta, Atika J (2002), Faktor-faktor yang Mempengaruhi Kebijakan Dividen: Investigasi Pengaruh Teori Stakeholder. JAAI Vol.6. No.2. Desember. 2002.

Indonesian Capital Market Directory (ICMD) 2007 - 2010

Jensen et al, 1992, "Simultaneous Determination of Insider Ownership, Debt, and Dividend Policies", Journal of Financial and Quantitative Analysis Vol 27

Rini Dwiyani. 2007. Analisis Faktor-faktor yang mempengaruhi Dividend Payout Ratio pada Perusahaan Manufaktur di Indonesia. Tesis. Universitas Sumatera Utara.

Risaptoko, RB,A (2007). "Analisis Pengaruh Cash Ratio, Debt to total asset, Asset Growth, Firm size, dan Return on Asset terhadap Dividen d Payout Ratio (Studi Komparatif pada Perusahaan yang Listed di BEJ yang Sahamnya Ikut Dimiliki Manajemen dan Yang Sahamnya Tidak Dimiliki Manajemen Periode Tahun 2002-5. Tesis yang Tidak Dipublikasikan.

Riyanto, Bambang. 2001. Dasar-Dasar Pembelanjaan Perusahaan. Yogyakarta: BPFE. Ross, Wasterfeld and Jordan. 2008. Corporate Finance Fundamental $8^{\text {th }}$ Edition.McGraw- Hill. 
Rozeff, M.S. (1982). Growth, Beta and Agency Cost as Determinants of Dividend Payout Ratios. Journal of Financial Research.

Sartono, Agus. 2001. "Kepemilikan Orang Dalam (Insider Ownership), Utang, dan Kebijakan Dividen: Pengujian Empirik Teori Keagenan (Agency Theory)".

Saxena, Atul K (1999), Determinant of Dividend Payout Policy: Regulated Versus

Unregulated Firms, The Journal of Finance.

Sutrisno. 1999. Analisis Faktor-faktor yang Mempengaruhi Dividend payout ratio pada

Perusahaan Publik di Indonesia. FE-Unibraw, Malang.

Winatha,I,K (2001). "Pengaruh Kebijakan Dividen terhadap Harga Saham Perusahaan Manufaktur di Indonesia yang Masuk Bursa Efek Jakarta". Laporan Penelitian Universitas Lampung. www.google.co

Yuniningsih (2002). "Interdependensi antara Kebijakan Dividen Payout Ratio, Financial leverage, dan Investasi pada Perusahaan Manufaktur yang Listed di Bursa Efek Jakarta" Jurnal Bisnis dan Ekonomi

www.idx.co 